\title{
The Effect of Cadmium on COX-1 and COX-2 Gene, Protein Expression, and Enzymatic Activity in THP-1 Macrophages
}

\author{
Tomasz Olszowski • Izabela Gutowska • \\ Irena Baranowska-Bosiacka • Katarzyna Piotrowska • \\ Jan Korbecki • Mateusz Kurzawski • Dariusz Chlubek
}

Received: 2 December 2014 / Accepted: 11 January 2015 / Published online: 3 February 2015

(C) The Author(s) 2015. This article is published with open access at Springerlink.com

\begin{abstract}
The aim of this study was to examine the effects of cadmium in concentrations relevant to those detected in human serum on cyclooxygenase-1 (COX-1) and cyclooxygenase-2 (COX-2) expression at mRNA, protein, and enzyme activity levels in THP-1 macrophages. Macrophages were incubated with various cadmium chloride $\left(\mathrm{CdCl}_{2}\right)$ solutions for $48 \mathrm{~h}$ at final concentrations of $5 \mathrm{nM}$, $20 \mathrm{nM}, 200 \mathrm{nM}$, and $2 \mu \mathrm{M} \mathrm{CdCl}_{2}$. The mRNA expression and protein levels of COXs were analyzed with RT-PCR and Western blotting, respectively. Prostaglandin $\mathrm{E}_{2}\left(\mathrm{PGE}_{2}\right)$ and stable metabolite of thromboxane $\mathrm{B}_{2}\left(\mathrm{TXB}_{2}\right)$ concentrations in culture media were determined using ELISA method. Our study demonstrates that cadmium at the highest tested concentrations modulates COX-1 and COX-2 at mRNA level in THP-1 macrophages; however, the lower tested cadmium concentrations appear to inhibit COX-1 protein expression. $\mathrm{PGE}_{2}$ and $\mathrm{TXB}_{2}$ production is not altered by all tested $\mathrm{Cd}$
\end{abstract}

\section{T. Olszowski}

Department of Hygiene and Epidemiology, Pomeranian Medical University, Powstańców Wlkp. 72 Av, 70-111 Szczecin, Poland

\section{Gutowska}

Department of Biochemistry and Human Nutrition, Pomeranian Medical University, Broniewskiego 24 Str, 71-460 Szczecin, Poland

I. Baranowska-Bosiacka $(\square) \cdot J$. Korbecki $\cdot$ D. Chlubek Department of Biochemistry and Medical Chemistry, Pomeranian Medical University, Powstańców Wlkp. 72 Av,

70-111 Szczecin, Poland

e-mail: ika@pum.edu.pl

K. Piotrowska

Department of Physiology, Pomeranian Medical University, Powstańców Wlkp. 72 Av, 70-111 Szczecin, Poland

\section{Kurzawski}

Department of Experimental and Clinical Pharmacology, Pomeranian Medical University, Powstańców Wlkp. 72 Av, 70-111 Szczecin, Poland concentrations; however, the significant stimulation of $\mathrm{PGE}_{2}$ and $\mathrm{TXB}_{2}$ production is observed when macrophages are exposed to both cadmium and COX-2 selective inhibitor, NS398. The stimulatory effect of cadmium on COXs at mRNA level is not reflected at protein and enzymatic activity levels, suggesting the existence of some posttranscriptional, translational, and posttranslational events that result in silencing of those genes' expression.

Keywords Cadmium · Cyclooxygenase-1 . Cyclooxygenase-2 $\cdot$ Prostaglandin $\mathrm{E}_{2} \cdot$ Thromboxane $\mathrm{B}_{2}$. THP-1 macrophages

\section{Introduction}

Cyclooxygenase-1 (COX-1) and cyclooxygenase-2 (COX-2) are the bifunctional enzymes catalyzing the conversion of arachidonic acid (AA) to prostaglandin $\mathrm{H}_{2}\left(\mathrm{PGH}_{2}\right)$ in two sequential reactions, the first being the generation of prostaglandin $\mathrm{G}_{2}\left(\mathrm{PGG}_{2}\right)$ (cyclooxygenase reaction) followed by the reduction of $\mathrm{PGG}_{2}$ to $\mathrm{PGH}_{2}$ (peroxidase reaction). The generated $\mathrm{PGH}_{2}$ is the precursor of biologically active prostanoids such as prostaglandin $\mathrm{D}_{2}\left(\mathrm{PGD}_{2}\right)$, prostaglandin $\mathrm{E}_{2}\left(\mathrm{PGE}_{2}\right)$, prostaglandin $\mathrm{I}_{2}\left(\mathrm{PGI}_{2}\right)$, prostaglandin $\mathrm{F}_{2 \alpha}\left(\mathrm{PGF}_{2 \alpha}\right)$ and thromboxane $\mathrm{A}_{2}\left(\mathrm{TXA}_{2}\right)[1,2]$. COX-1 and COX-2 enzymes share $60 \%$ identity in their amino acid sequences [3]. They exist as homodimers; each subunit consists of three domains, the epidermal growth factor domain, the membrane binding domain, and the catalytic domain containing the cyclooxygenase and peroxidase active sites [3].

COX-1, constitutively expressed in almost all cell types, but also inducible in some systems [4], was previously considered to be involved in physiological processes and playing 
no role in inflammation [4]. However, according to newer concept, COX-1 is also involved in inflammatory process [2, 5]; for example, COX-1 not only is responsible for the initial prostanoid response to inflammatory stimuli [6] but also contributes to the resolution of inflammation [4]. The human COX-1 gene (Ptgs 1 ) expression is developmentally controlled and can be upregulated by tumor-promoting phorbol esters or growth factors [7]. The regulatory elements of this gene include SP1 binding site and activator protein-1 (AP-1) site [4, 7]; however, the transcriptional control of COX-1 gene expression was not well studied [7]. The products of COX-1 enzyme are thromboxane $\mathrm{A}_{2}$ (being metabolized to its stable metabolite, $\left.\mathrm{TXB}_{2}\right)$ and $\left(\mathrm{PGE}_{2}[6]\right.$.

$\mathrm{COX}-2$ is an enzyme highly inducible by pro-inflammatory cytokines, tumor promoters, mitogens, and growth factors in a variety of cell types, including monocytes [8], which results in increased prostaglandin release [5]. According to newer concept, COX-2 is the major contributor to prostanoid synthesis as inflammation progresses [6]. COX-2 gene (Ptgs2) contains several potential transcriptional regulatory elements in the 5'flanking region: peroxisome proliferator response element (PPRE), two nuclear factor kappa B (NF-kB) sites, one specificity protein 1 (Sp1) site, two cyclic AMP response elements (CRE), one nuclear factor for interleukin-6 expression (NFIL6) motif, two AP-1 sites, E-box, and TATA box [4, 7, 9]. Transcriptional regulation of COX-2 gene is very complex; it can involve numerous signaling pathways, and the mechanism varies depending on the specific stimulus and the cell type [7]. The main product of COX-2 enzyme is $\mathrm{PGE}_{2}[6]$.

Cadmium is a toxic and carcinogenic heavy metal that poses nowadays a serious threat to human health because it is ubiquitously distributed in the environment and the food, tobacco smoke, and ambient air constitute the most significant sources of cadmium exposure for the general population [10, 11]. Cadmium was found to be immunomodulator; it may modify cell-mediated and humoral immune response, which may be associated with the occurrence of allergic, inflammatory diseases, and cancers $[12,13]$. The target cells for heavy metals action such as cadmium are lymphocytes and macrophages, which participate in humoral immune response. As a result of toxic action of cadmium, the pro-inflammatory, procoagulatory, and chemotactic factors are released, activating macrophages to produce cytokines and to development of the further stages of immune reaction [12]. Cadmium was found to cause upregulation of some mediators and markers of inflammation [11]. A number of studies investigated the effect of cadmium on COX-2 mRNA [8, 14-19], protein expression $[14,16,18,20-25]$, and enzymatic activity $[16-18,24,26$, 27]. Most of them demonstrated a stimulatory effect of this metal on COX-2 in different experimental models [8, 16-19, 21-27]. However, a few reports suggested cadmium to exert either inhibitory action $[14,15]$ or no effect $[20]$ on COX-2.
The impact of cadmium on COX-1 was rather poorly analyzed in literature: only a few studies dealt with this issue, suggesting either no $[16,28]$ or stimulatory effect [17].

THP-1 cells model has some advantages over human macrophages isolated from blood of cadmium-exposed people. Their homogenous genetic background minimizes the degree of variability in the cell phenotype [29]. Such cell model eliminates the influence of other environmental factors that may interfere with the examined mechanisms of cadmium action. Therefore, THP-1 cells experimental system represents a convenient model for the studies of molecular mechanisms of cadmium action on macrophages in relation to inflammatory processes [29].

The aim of this study was to examine the effects of cadmium in low concentrations (relevant to levels detected in human serum) on activity and expression of COX-1 and COX-2.

\section{Materials and Methods}

\section{Materials}

The materials used include anti-mouse IgG FITC conjugated (Sigma-Aldrich, Poland), antibiotics (penicillin and streptomycin) (Sigma-Aldrich, Poland), Bakerbond columns (Witko Group, Poland), cadmium chloride (Sigma-Aldrich, Poland), cDNA Reverse Transcription Kit (Life Technologies, USA), COX-1 and COX-2 mouse monoclonal antibody (Santa Cruz, Germany), FBS (ALAB, Poland), goat anti-mouse IgG-HRP (Santa Cruz, Germany), Micro BCA Protein Assay kit (Thermo Scientific, USA), monoclonal anti- $\beta$-actin anti$\operatorname{body}(1: 200$; clone AC-74, Sigma Aldrich, Poland), nitrocellulose membrane (Thermo Scientific, Pierce Biotechnology, USA), NS-398 (Sigma-Aldrich, Poland), PBS (Biomed-Lublin, Poland), phorbol 12-myristate13-acetate (PMA) (Sigma-Aldrich, Poland), Precision Plus Protein Kaleidoscope Standards (Bio-Rad, Poland), Prostaglandin $\mathrm{E}_{2}$ EIA Kit (Cayman, USA), RNAqueous Mini Kit (Life Technologies, USA), RPMI medium (Biomed-Lublin, Poland), Super Signal West Pico Chemiluminescent Substrate (ALAB, Poland), Taqman Gene Expression Assays (Applied Biosystems, USA), THP-1 cells (American Type Culture Collection ATCC, Rockville, USA), and Thromboxane $\mathrm{B}_{2}$ EIA Kit (Cayman, USA).

\section{Cell Culture and Treatment}

The experiments were conducted on macrophages derived from a human monocytic cell line THP-1. The differentiation of THP-1 cells into macrophages was achieved by administration of $100 \mathrm{nM}$ PMA and further incubation for $24 \mathrm{~h}$. The adherent macrophages were washed three times with PBS and then incubated with cadmium chloride $\left(\mathrm{CdCl}_{2}\right)$ solutions for $48 \mathrm{~h}$ at $37^{\circ} \mathrm{C}$ in $5 \% \mathrm{CO}_{2}$. The following concentrations of 
$\mathrm{CdCl}_{2}$ were used in this study: $5 \mathrm{nM}, 20 \mathrm{nM}, 200 \mathrm{nM}$, and 2 $\mu \mathrm{M}$. They were selected based on the cadmium levels found in human serum [13]. In half of the culture dishes, the cadmium-exposed macrophages were additionally incubated with COX-2 selective inhibitor, NS-398 $(50 \mu \mathrm{M})$. After $48 \mathrm{~h}$, the cells were harvested by scraping and the pellets were obtained by centrifugation $(800 \times g, 10 \mathrm{~min})$. Afterwards, the cool PBS was added to the pellets and the samples were stored at $-80{ }^{\circ} \mathrm{C}$ until the following further analyses: the measurement of protein concentration using Micro BCA Protein Assay Kit (Thermo Scientific, Rockford, USA). The remaining supernatants were placed in new tubes and stored at $-80{ }^{\circ} \mathrm{C}$ until further analyses, that is the extraction and measurement of $\mathrm{PGE}_{2}$ and $\mathrm{TXB}_{2}$ by ELISA method.

Cyclooxygenase-1 and Cyclooxygenase-2 Gene Expression Analysis by qRT-PCR

The quantitative analysis of the expression of Ptgs 1 and Ptgs2 genes was performed in a two-step reverse transcription PCR. Total RNA was extracted from cells using RNAqueous Mini Kit (Life Technologies, USA). The quantity and quality of isolated RNA were determined using the Nanodrop ND-1000 spectrophotometer (NanoDrop Technologies, USA). cDNA was prepared from $400 \mathrm{ng}$ of total cellular RNA in $20 \mu \mathrm{l}$ of reaction volume, using High capacity cDNA Reverse Transcription Kit (Life Technologies, USA) with random primers, according to manufacturer's instructions. Quantitative real-time PCR was performed in 7500 Fast Real-Time PCR System (Applied Biosystems, USA), using pre-validated Taqman Gene Expression Assays (Applied Biosystems, USA) and a FAMlabeled probe for analyzed genes and a VIC-labeled probe for endogenous control gene: GAPDH, TaqMan GE Master Mix (Life Technologies, USA) and $1.5 \mu \mathrm{l}$ of cDNA for each reaction mix of $15 \mu \mathrm{l}$. Every sample was analyzed simultaneously in two technical replicates; the mean $C_{\mathrm{T}}$ values were used for further investigation. The relative quantification method was applied in calculations, using 7500 Fast Real-Time PCR System Software (Applied Biosystems, USA). The thresholds were set manually to compare data between runs and $C_{\mathrm{T}}$ values were extracted. All $C_{\mathrm{T}}$ values were normalized to the mean for endogenous controls $(G A P D H)$ for each sample. Analysis of these relative changes in gene expression between samples was performed using the $2^{-\Delta \Delta C}$ method.

The Measurements of Cyclooxygenase-1 and Cyclooxygenase-2 Expression by Western Blotting

Scraping of cells was followed by lysis using lysing buffer (protease inhibitor, ethylenediaminetetraacetic acid $5 \mathrm{mM}$; Sigma Aldrich, Poland) and cell lysates were collected in $-80{ }^{\circ} \mathrm{C}$. Separation of equal amounts of protein $(20 \mu \mathrm{g})$ was performed in $10 \%$ sodium dodecylsulfate (SDS)/ polyacrylamide gel electrophoresis followed by transfer to a nitrocellulose membrane (Thermo Scientific, Pierce Biotechnology, USA) at $157 \mathrm{~mA}$ for $1.5 \mathrm{~h}$ at room temperature. After blocking the membrane with $5 \%$ (COX-1) or $3 \%(\mathrm{COX}-2)$ non-fat milk in Tris-buffered saline (Sigma Aldrich, Poland) containing $0.1 \%$ Tween 20 (Sigma Aldrich, Poland) for $1 \mathrm{~h}$ at room temperature, it was incubated with primary antibodies direct against COX-1 and COX-2 (1:200; Santa Cruz Biotechnology, USA) or with a monoclonal anti- $\beta$-actin (1:200; clone AC-74, Sigma Aldrich, Poland) and next with secondary antibodies (goat anti-mouse IgG HRP, 1:2,000; Santa Cruz Biotechnology, USA). Signals were visualized by chemiluminescence (Thermo Scientific, Pierce Biotechnology, USA).

The Measurements of Prostaglandin $\mathrm{E}_{2}$ and Thromboxane $\mathrm{B}_{2}$ Concentrations

$\mathrm{PGE}_{2}$ and $\mathrm{TXB}_{2}$ were extracted from culture supernatants using Bakerbond columns (Witko Group, Poland). The measurements of $\mathrm{PGE}_{2}$ and $\mathrm{TXB}_{2}$ levels were conducted using appropriate immunoenzymatic sets (Prostaglandin $E_{2}$ EIA Kit, Cayman, USA; Thromboxane $\mathrm{B}_{2}$ EIA Kit, Cayman, USA) according to manufacturers' instruction.

Imaging of Cyclooxygenase-1 and Cyclooxygenase-2 Expression

Expression of COX-1 and COX-2 proteins was examined with confocal microscopy. THP-1 macrophages were grown on cover glasses in standard in vitro culture conditions. Further, cells were washed with PBS and fixed with $4 \%$ buffered formalin for $15 \mathrm{~min}$ in room temperature. After the fixation and washing with PBS, cells were permeabilized with $0.5 \%$ solution of Triton X-100 in PBS. After washing with fresh portion of PBS, cells were incubated with primary antibodies: mouse anti-COX-1 and mouse anti-COX-2 (Santa Cruz Biotechnology) in 1:50 dilution, in $4{ }^{\circ} \mathrm{C}$, overnight and then washed and incubated with secondary antibody: anti-mouse IgG FITC conjugated, dilution 1:60 (Sigma-Aldrich) in antibody diluent (Dako), $30 \mathrm{~min}$ in room temperature and after washing with PBS further with Hoechst 33258, 30 min, room temperature. The cells were examined under a confocal microscope (FV1000 confocal with IX81 inverted microscope, Olympus, Germany); three channel acquisition and sequential scanning were used for best resolution of signal from Hoechst 33258 and FITC fluorescence. Additionally, fluorescent images were merged with transition light images.

Statistical Analysis

The statistical analysis of obtained results was conducted using Statistica 10 software (Statsoft, Poland). The results were expressed as arithmetical mean \pm standard deviation 
(SD). The distribution of variables was evaluated using Shapiro-Wilk $W$ test. The nonparametric tests were used for further analyses because distribution in most cases deviated from normal distribution. The results were subjected to Wilcoxon matched-pair test. The level of significance was set at $p<0.05$.

\section{Results}

Cadmium at Highest Tested Concentrations Increases Cyclooxygenase-1 mRNA Expression, While at Low Tested Concentrations Decreases Protein Expression in THP-1 Macrophages

In macrophages cultured with $\mathrm{CdCl}_{2}$, the mRNA expression of COX-1 significantly increased ( $35 \%)(p=0.043)$ for $2 \mu \mathrm{M}$ cadmium solution ( $p=0.043$ ) (Fig. 1). Addition of NS-398 (COX-2 selective inhibitor) to cultures caused significant upregulation of COX-1 mRNA for $20 \mathrm{nM}(p=0.043)$ and $2 \mu \mathrm{M}(p=0.043)$ cadmium solution ( 29 and $84 \%$ increase, respectively).

The estimation of the effects of cadmium on COX-1 protein expression was performed using Western blot and immunocytochemistry. The results obtained using these two methods are consistent. COX-1 protein expression decreased markedly following exposure to $20 \mathrm{nM}(p=0.012)$ and 200 $\mathrm{nM}(p=0.012)$ cadmium solution (19.5 and $27 \%$ decrease, respectively) (Fig. 1b and c). The images taken by fluorescence microscopy confirmed the influence of cadmium solution on the decrease in COX-1 protein expression (Fig. 2).

Cadmium at Highest Tested Concentrations Increases Cyclooxygenase-2 mRNA Expression, While It Exerts No Effect on Protein Levels in THP-1 Macrophages

COX-2 mRNA expression increased in a cadmium concentration-dependent manner, with significant upregulation for $200 \mathrm{nM}(p=0.043)$ and $2 \mu \mathrm{M}(p=0.027)$ cadmium
Fig. 1 The effect of cadmium on COX-1 mRNA and protein expression in macrophages cultured with various cadmium solutions. a COX-1 mRNA expression following cadmium exposure without or with addition of COX-2 selective inhibitor, NS-398; b COX-1 protein expression (densitometric analysis of protein normalized to $\beta$-actin; $\mathbf{c}$ representative Western blot following cadmium exposure. Monocytes/ macrophages were cultured with cadmium solutions for $48 \mathrm{~h}$. After incubation, cells were harvested by scraping and mRNA was measured by using real-time PCR method $(n=4)$ and protein expression by using Western blotting method $(n=3)$. Asterisk, statistically significant as compared with $0 \mathrm{nM} \mathrm{Cd}$ - cells incubated in RPMI medium with $10 \%$ FBS and with DMSO addition (Wilcoxon test). Number sign, statistically significant as compared with the experiment $0 \mathrm{nM}$ Cd with NS-398 (Wilcoxon test)

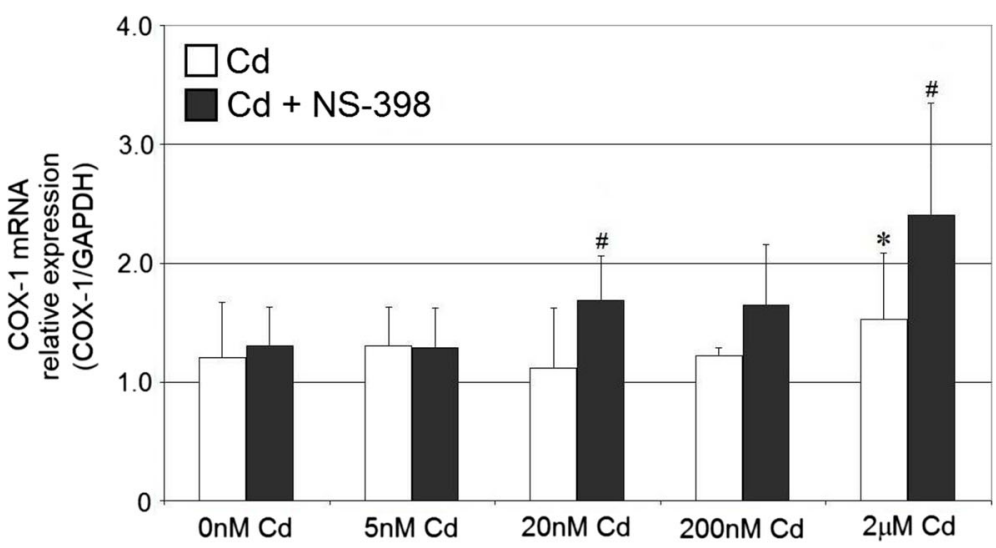

A

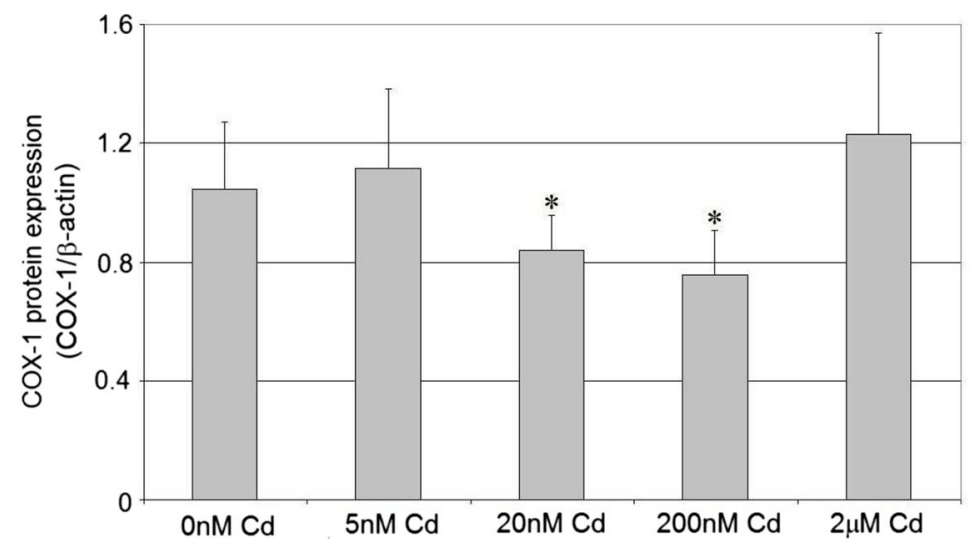

B 
Fig. 2 Imaging of COX-1 enzyme by fluorescence microscopy in macrophages cultured with cadmium. Monocytes/ macrophages were cultured with $\mathrm{Cd}$ solutions for $48 \mathrm{~h}$. The immunohistochemistry was performed using specific primary antibody, mouse anti-COX-1 (the overnight incubation at $4{ }^{\circ} \mathrm{C}$ ), and secondary antibodies conjugated with flouorochrome-anti-mouse IgG FITC (incubation for $45 \mathrm{~min}$ at room temperature). The nuclei of cells were DAPI stained. Image analysis was performed with a fluorescent microscope using filters 38 HE GFP for green fluorescence and 49 DAPI for blue fluorescence
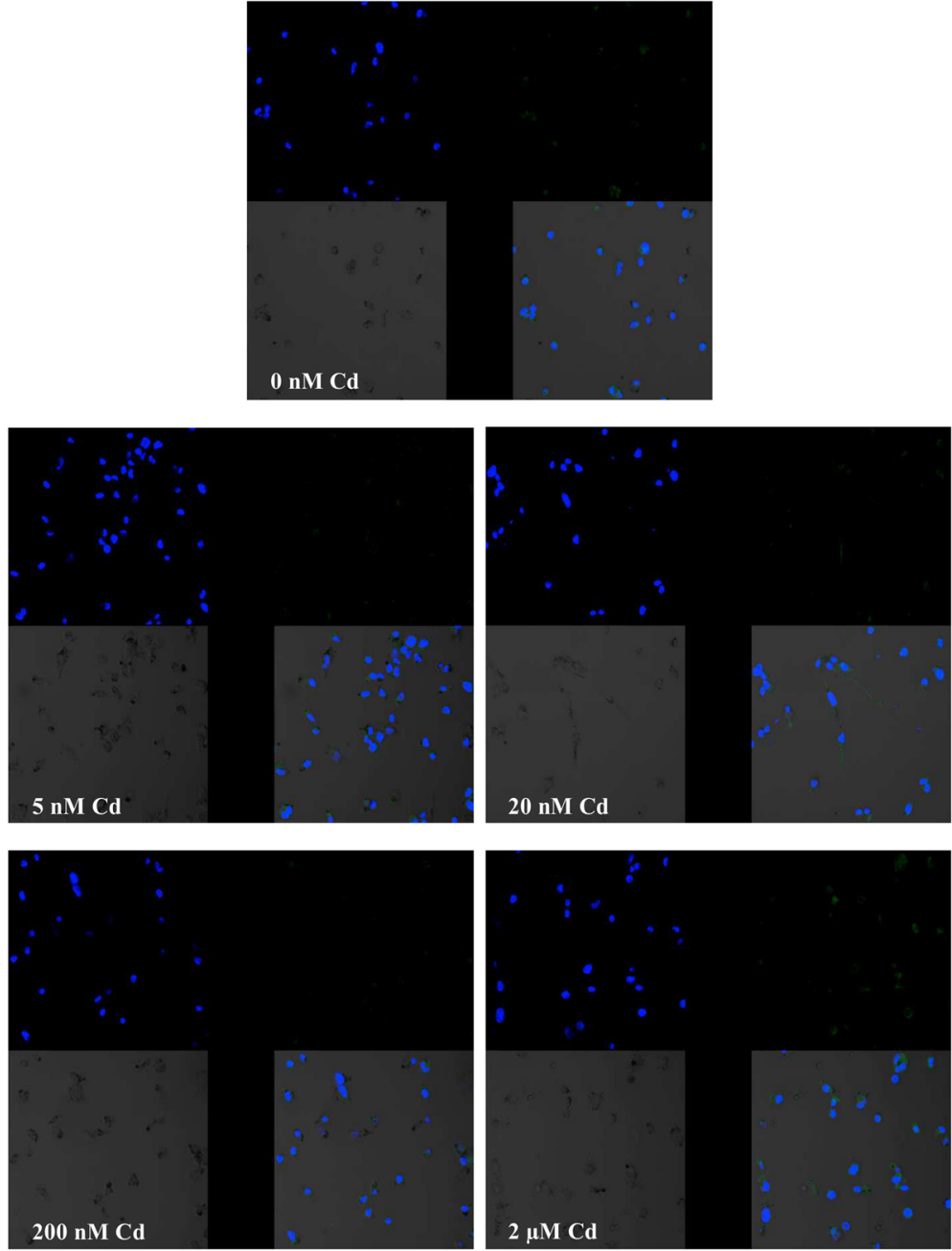

solution (18.5 and $40 \%$ increase, respectively) (Fig. 3a). Addition of COX-2 selective inhibitor, NS-398 to cultures did not modulate significantly COX-2 mRNA expression at most cadmium concentrations tested; however, the interaction of cadmium at very low concentration $(5 \mathrm{nM} ; p=0.046)$ and NS-398 resulted in significant downregulation of COX-2 mRNA expression ( $p=0.046)$ ( $22 \%$ decrease).

The estimation of the effects of cadmium on COX-2 protein expression was performed using Western blot and immunocytochemistry. The results obtained using these two methods are consistent. Cadmium at all concentrations tested in this study did not alter significantly COX-2 protein expression (Fig. $3 \mathrm{~b}$ and c). The images taken by fluorescence microscopy confirmed no effect of cadmium solution on COX-2 protein expression (Fig. 4).

\section{Prostaglandin $\mathrm{E}_{2}$ Production Is Unaltered by Cadmium Treatment in THP-1 Macrophages}

Cadmium used in this study did not significantly affect $\mathrm{PGE}_{2}$ concentrations as compared to control (Fig. 5).
However, the treatment of THP-1 macrophages with both cadmium and NS-398 caused significant dose-dependent increase (262 to $488 \%$ ) in $\mathrm{PGE}_{2}$ concentration as compared to control ( $p=0.027$ for $5 \mathrm{nM} ; p=0.027$ for $20 \mathrm{nM} ; p=0.043$ for $200 \mathrm{nM}$; and $p=0.043$ for $2 \mu \mathrm{M}$ cadmium solutions).

Cadmium at All Tested Concentrations Does Not Significantly Affect Thromboxane $\mathrm{A}_{2}$ Production in THP-1 Macrophages

Treatment of THP-1 macrophages at 200 and 2,000 nM of cadmium resulted in insignificant decrease (19 to $41 \%$ ) in $\mathrm{TXB}_{2}$ concentrations as compared to control (Fig. 6). However, co-incubation of macrophages with cadmium and selective COX-2 inhibitor, NS-398, resulted in the opposite effect, that is increase ( 28 to $153 \%$ ) in $\mathrm{TXB}_{2}$ concentration, with the highest tested cadmium concentration $(2 \mu \mathrm{M} \mathrm{Cd})$ causing marked increase ( $153 \%)$ in $\mathrm{TXB}_{2}$ level, as compared to control $(p=0.043)$. Addition of NS-398 to cadmium treated macrophages' cultures caused significant increase in $\mathrm{TXB}_{2}$ 
Fig. 3 The effect of cadmium on COX-2 mRNA and protein expression in macrophages cultured with various cadmium solutions. a COX-2 mRNA expression following cadmium exposure without or with addition of COX-2 selective inhibitor, NS-398; b COX-2 protein expression (densitometric analysis of protein normalized to $\beta$-actin; $\mathbf{c}$ representative Western blot following cadmium exposure. Monocytes/ macrophages were cultured with cadmium solutions for $48 \mathrm{~h}$. After incubation, cells were harvested by scraping and mRNA was measured by using real-time PCR method $(n=4)$ and protein expression by using Western blotting method $(n=3)$. Asterisk, statistically significant as compared with $0 \mathrm{nM} \mathrm{Cd}$ - cells incubated in RPMI medium with $10 \%$ FBS and with DMSO addition (Wilcoxon test). Number sign, statistically significant as compared with the experiment $0 \mathrm{nM}$ Cd with NS-398 (Wilcoxon test)

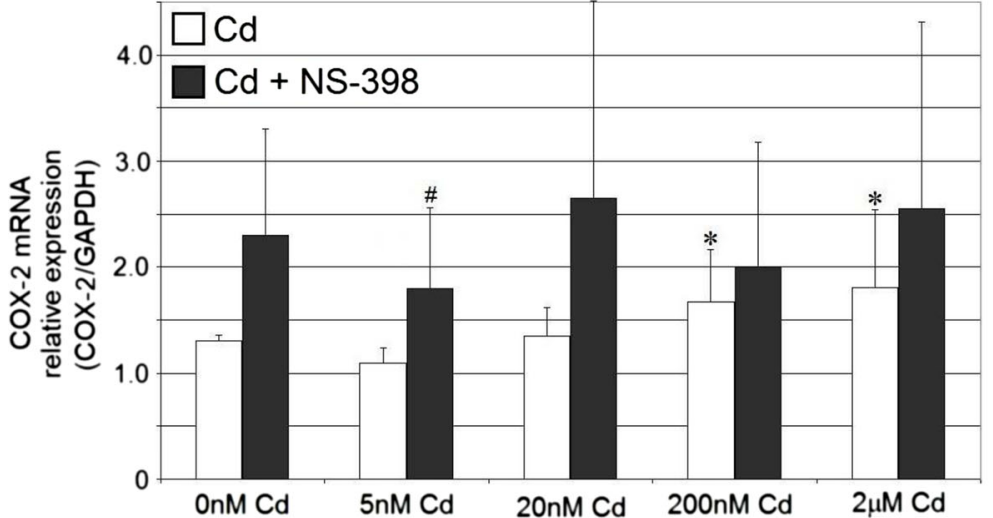

A

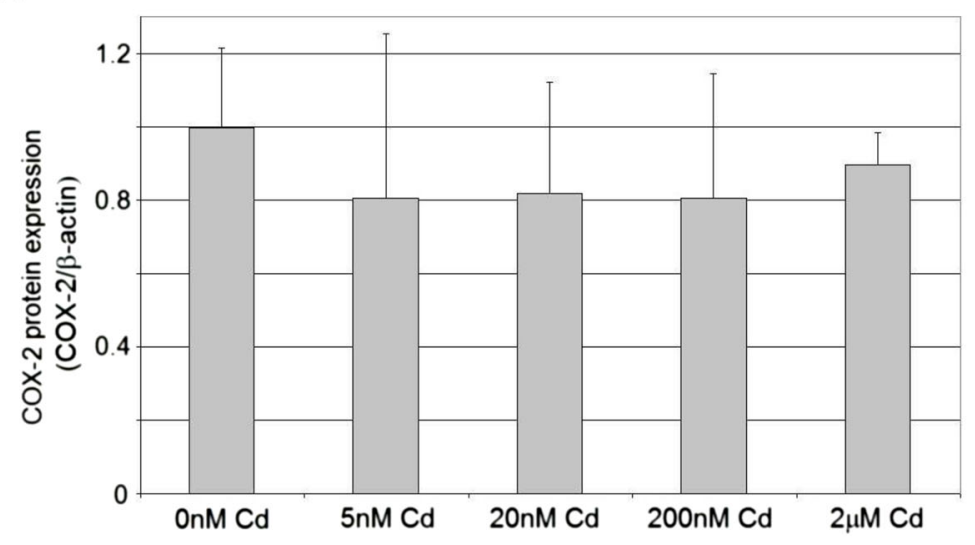

B

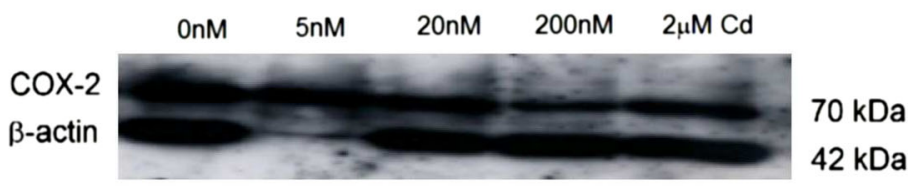

production for $20 \mathrm{nM}(p=0.05), 200 \mathrm{nM}(p=0.05)$, and $2 \mu \mathrm{M}$ $(p=0.043)$ cadmium solutions.

\section{Discussion}

The current study, to the best of our knowledge, is the first such study in which the effects of very low and low concentrations of cadmium (comparable to those occurring in the blood serum of general population or occupationally exposed workers) on inflammatory enzymes such as COX-1 and COX-2 and their products were analyzed using THP-1 macrophage experimental system.

Cadmium and Cyclooxygenases mRNA Expression

We demonstrated that $48 \mathrm{~h}$ treatment of THP-1 macrophages with $2 \mu \mathrm{M}$ cadmium significantly increased COX-1 mRNA expression. Similar results were reported by Miyahara et al. who showed that cadmium at $1 \mu \mathrm{M}$ and above significantly increased the level of COX-1 mRNA in primary mouse osteoblastic cells [17]. The opposite results were reported by Figueiredo-Pereira et al.; the authors demonstrated that COX-1 gene expression was not upregulated by cadmium treatment $(3-30 \mu \mathrm{M})$ in HT4 mouse neuronal cells [16].

The observed increased COX-1 mRNA expression due to the highest tested cadmium concentration may be explained by several mechanisms. COX-1 gene regulatory elements include three SP1 binding sites and AP-1 binding site [7]. Cadmium, in concentration range $0.5-20 \mu \mathrm{M}$, was found to induce the expression of c-fos and c-jun genes (genes that constitute AP-1 transcription factor) in different biological systems [30,31]. We speculate that $48 \mathrm{~h}$ exposure of macrophages to $2 \mu \mathrm{M} \mathrm{Cd}$ might significantly activate AP-1 transcription factor, which in turn could significantly induce COX-1 gene promoter through enhanced binding AP-1 to DNA, resulting in increased COX-1 mRNA levels. Another possible mechanism responsible for increased COX-1 mRNA expression due to cadmium may be cadmium effects on secondary messengers, such as ROS or intracellular $\mathrm{Ca}^{2+}[10]$. Although cadmium is not a Fenton metal, it causes generation of 
Fig. 4 Imaging of COX-2 enzyme by fluorescence microscopy in macrophages cultured with cadmium. Monocytes/ macrophages were cultured with $\mathrm{Cd}$ solutions for $48 \mathrm{~h}$. The immunohistochemistry was performed using specific primary antibody, mouse anti-COX-2 (the overnight incubation at $4{ }^{\circ} \mathrm{C}$ ), and secondary antibodies conjugated with flouorochrome-anti-mouse IgG FITC (incubation for $45 \mathrm{~min}$ at room temperature). The nuclei of cells were DAPI stained. Image analysis was performed with a fluorescent microscope using filters 38 HE GFP for green fluorescence and 49 DAPI for blue fluorescence
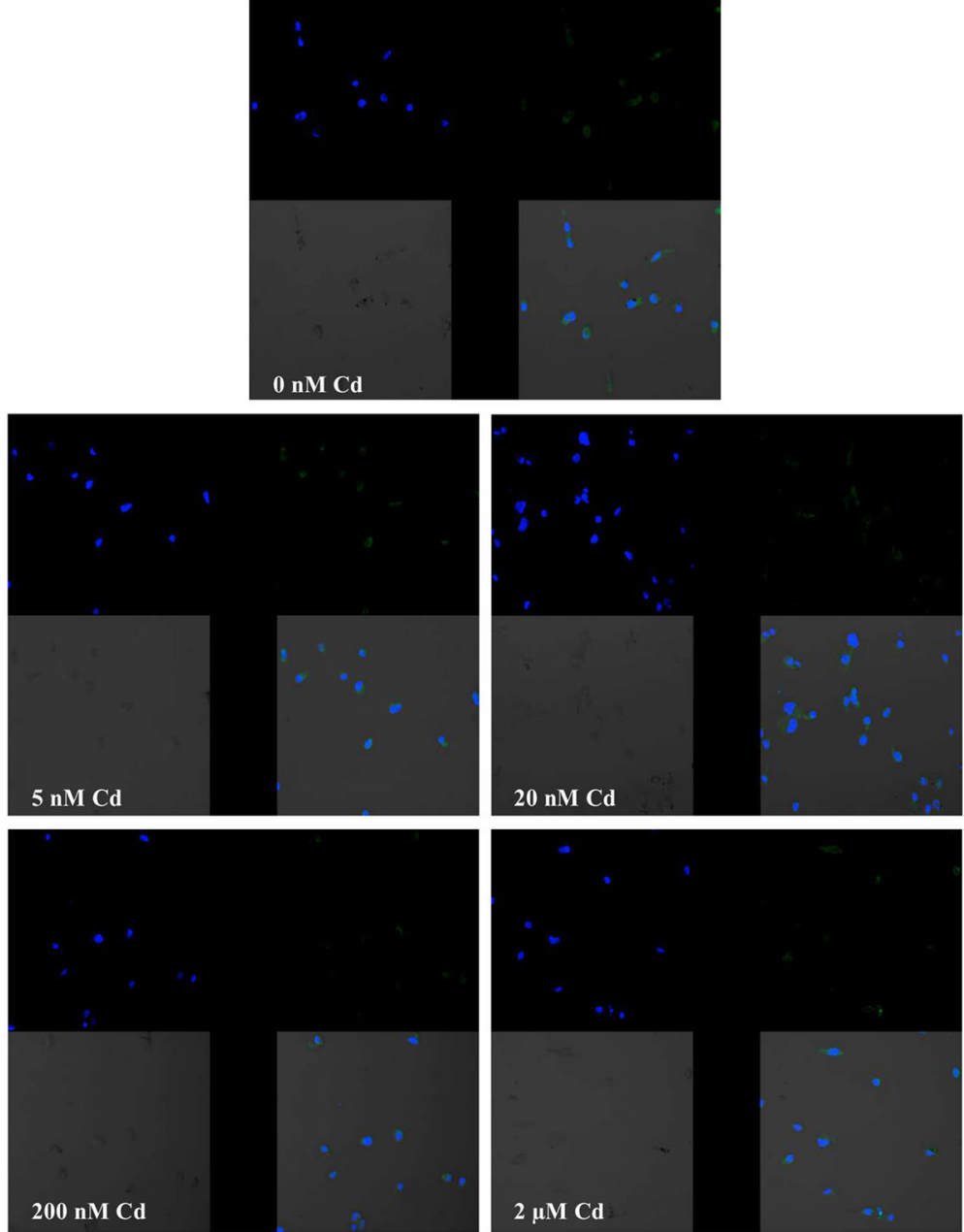

ROS; elevated levels of ROS might affect the redox-sensitive transcription factor AP-1, which could bind to appropriate COX-1 gene promoter regulatory element, and thus stimulate COX-1 mRNA expression [31]. Moreover, cadmium might

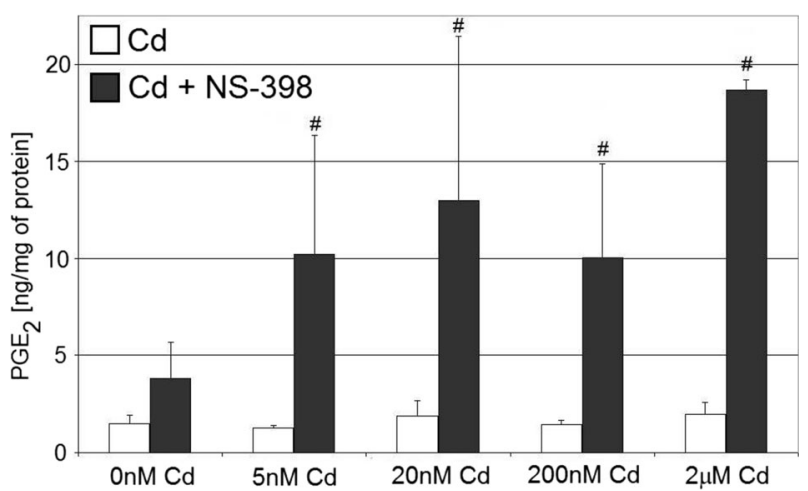

Fig. 5 The effect of cadmium on quantity of $\mathrm{PGE}_{2}$ in culture supernatants of macrophages cultured with various cadmium solutions. Monocytes/macrophages were cultured with cadmium solutions for $48 \mathrm{~h}$. After incubation, cells were harvested by scraping and $\mathrm{PGE}_{2}$ concentration was measured by ELISA method $(n=6)$. Number sign, statistically significant as compared with the experiment $0 \mathrm{nM}$ Cd with NS-398 (Wilcoxon test) activate protein kinases (such as protein kinase $\mathrm{C}$ ) through the increased levels of intracellular $\mathrm{Ca}^{2+}$, resulting in enhanced phosphorylation of AP-1 transcription factor leading to transcriptional activation of COX-1 gene [10, 32].

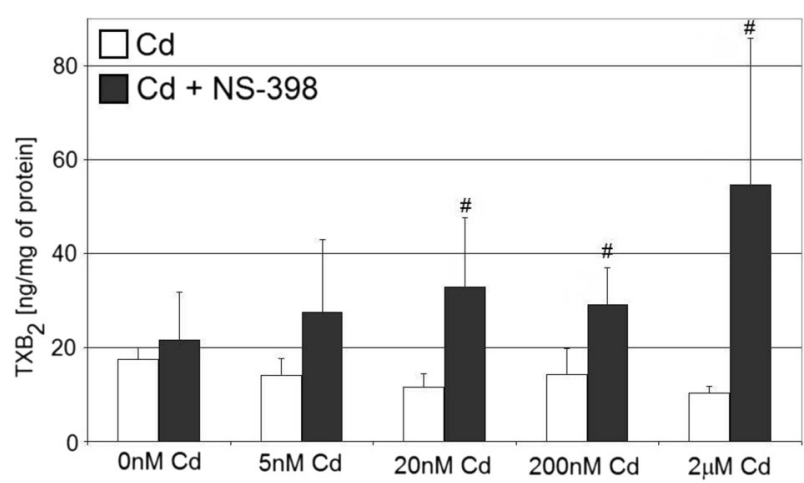

Fig. 6 The effect of cadmium on quantity of $\mathrm{TXB}_{2}$ in culture supernatants of macrophages cultured with various cadmium solutions. Monocytes/macrophages were cultured with cadmium solutions for $48 \mathrm{~h}$. After incubation, cells were harvested by scraping and $\mathrm{TXB}_{2}$ concentration was measured by ELISA method $(n=6)$. Number sign, statistically significant as compared with the experiment $0 \mathrm{nM} \mathrm{Cd}$ with NS-398 (Wilcoxon test) 
Addition of NS-398 to macrophage cultures treated with cadmium resulted in significant increase in COX-1 mRNA expression (for $20 \mathrm{nM}$ and $2 \mu \mathrm{M} \mathrm{Cd}$ ). Selective COX-2 inhibitor NS-398 seems to enhance the stimulatory effect of cadmium on COX-1 mRNA levels.

Cadmium at concentrations $200 \mathrm{nM}$ and $2 \mu \mathrm{M}$ markedly upregulated COX-2 mRNA expression in THP-1 macrophages treated for $48 \mathrm{~h}$. These results are in agreement with the results of the studies of Miyahara et al. [17], Figueiredo-Pereira et al. [16], Shin et al. [19], Seok et al. [18], and Park et al. [8]; however, it should be stressed that other experimental systems and usually higher cadmium concentrations were used by those authors. In contrast, two other studies showed the downregulation of COX-2 mRNA expression by cadmium [14, 15].

With respect to COX-2 gene transcriptional regulation, its promoter contains many cis-acting regulatory elements, of them only NF- $\mathrm{BB}$ site, CRE, NF-IL6 motifs, and E-box are known to be involved in the regulation of COX-2 gene expression $[9,33]$. Transcription factors bind to these sites in a variety of combinations depending on cell type and also which regulatory pathway is activated [9]. Cadmium was found to activate NF- $\mathrm{KB}$ transcription factor [31]. We speculate that cadmium in higher tested concentrations (i.e., $200 \mathrm{nM}$ and 2 $\mu \mathrm{M}$ ) might cause marked upregulation of NF- $\mathrm{B}$, enhanced binding of NF- $\mathrm{kB}$ to $\mathrm{COX}-2$ promoter, and $\mathrm{COX}-2$ promoter activation leading to increased COX-2 mRNA expression. Similarly to COX-1 gene, also other mechanisms may be responsible for increased expression of COX-2 gene by cadmium, including effects on secondary messengers (ROS, intracellular $\mathrm{Ca}^{2+}$ ) and effects on signal transduction cascades involving kinases [10, 31]. For example, cadmium appeared to activate the following kinases: protein kinase $\mathrm{C}$, mitogenactivated protein kinase (MAPK) family (ERK, JNK, p38), stress-activated protein kinase, casein kinase 2, calcium/ calmodulin-dependent kinase II [31].

In our study, incubation of macrophages with cadmium and COX-2 selective inhibitor, NS-398, did not change significantly the COX-2 mRNA expression at most $\mathrm{Cd}$ concentrations tested; however, the lowest $\mathrm{Cd}$ concentration with NS398 caused significant downregulation of COX-2 mRNA level. NS-398 appears to counteract the stimulatory effect of $\mathrm{Cd}$ on COX-2 mRNA levels. Our results seem to be in concert with the report of Callejas et al., who found that the interaction of NS-398 and LPS on COX-2 upregulation was not observed at the mRNA level [34]. In contrast to this, Blais et al. demonstrated that NS-398 enhanced the effects of LPS on transcriptional activation of key inflammatory molecules [35].

Cadmium and Cyclooxygenase-1 and Cyclooxygenase-2 Protein Expression

The expression of COX-1 protein in THP-1 macrophages, as determined by Western blotting, decreased significantly following
$48 \mathrm{~h}$ exposure to 20 and $200 \mathrm{nM} \mathrm{Cd}$. Unfortunately, no studies have been found in the literature which dealt specifically with the effects of cadmium on COX-1 at protein level. Barrios-Rodiles et al. demonstrated that the level of COX-1 remained unaltered in PMA-differentiated THP-1 macrophages stimulated by other inflammatory stimulant which is LPS itself and pretreated with NS398 [36]. Maybe the reason for the scarce of reports was the former opinion that COX-1 is a constitutive enzyme and does not change during inflammation [4]. However, this opinion appeared to be simplistic. Later on, there was suggestion that COX1 contributes to inflammatory response [5], so the recent view is that both COX-1 and COX-2 enzymes show their activities under both physiological and pathological conditions, such as inflammation $[5,6]$.

As mentioned previously, cadmium at concentrations 20 and $200 \mathrm{nM}$ exerted inhibitory effect on COX-1 protein level in THP-1 macrophages despite the absence of alterations in COX-1 mRNA level. The observed discrepancy between COX-1 mRNA and protein levels is not unique, since Gry et al. compared mRNA and protein profiles of 1,066 gene products in 23 human cell lines and found significant correlations only in one third of examined mRNA species and corresponding proteins [37]. This rather weak correlation between COX-1 mRNA and protein levels suggests the existence of some nonspecific effect of cadmium resulting in suppression of COX-1 mRNA translation. Probably, the possible mechanisms of COX1 protein downregulation by cadmium might involve the following: changes in its mRNA stability [9], enhanced COX-1 degradation [7], interaction with COX-1 mRNA binding proteins leading to inhibition of COX-1 protein synthesis [38], effects on translation factors [39] (for example, $\mathrm{CdCl}_{2}$ caused significant decrease in protein level of translation initiation factor $4 \mathrm{E}$, eIF4E). Similar regulatory mechanisms may also be responsible for the lack of marked alterations in COX-1 protein expression due at $2 \mu \mathrm{M}$ cadmium concentration despite significant upregulation of COX-1 mRNA levels [9, 33, 40].

In our study, the expression of COX-2 protein in THP-1 macrophages was not significantly modulated by cadmium at all tested concentrations. This result is in agreement with the results obtained by Alvarez et al. who showed that cadmium (given to rats in concentration of $15 \mathrm{ppm}$ in drinking water for 3 months) did not modify the expression of COX-2 in rat prostate [20]. Ahn et al. reported even suppression of COX2 expression induced by LPS in RAW 264.7 macrophages by cadmium [14]. However, it is worth mentioning that most of available reports demonstrated significant increase in COX-2 protein expression due to cadmium exposure [16, 18, 21-25].

The observed absence of alterations in COX-2 protein levels despite significant upregulation of its mRNA following $48 \mathrm{~h}$ exposure to $200 \mathrm{nM}$ and $2 \mu \mathrm{M} \mathrm{Cd}$ remains to be elucidated. However, one must remember that the regulation of COX-2 gene expression is very complex, and this heavy metal may modulate many regulatory mechanisms that operate at 
different levels $[30,38]$. We may not exclude cadmiummediated suppression of COX-2 protein translation, mechanisms of which might be similar to those described by us as potential modulators of COX-1 protein translation. We speculate that the possible effects of cadmium on COX-2 protein levels might involve the following: changes in COX-2 mRNA stability [33], the effect on RNA-binding proteins [9], the effect on miRNAs [7, 41], enhanced COX-2 degradation [7, $38]$, the effect on translation factors [7, 39].

Cadmium and Prostaglandin $E_{2}$ Synthesis by THP-1 Macrophages

Cadmium at the concentrations $5 \mathrm{nM}-2 \mu \mathrm{M}$ did not significantly modify the $\mathrm{PGE}_{2}$ levels in THP-1 macrophages medium following $48 \mathrm{~h}$ exposure. This result is in contrast to other study results which demonstrated stimulatory effect of cadmium (in general in concentrations of $1 \mu \mathrm{M}$ and above) on $\mathrm{PGE}_{2}$ production by different cells like HT4 mouse neuronal cells [16], murine cerebrovascular endothelial cells [18], mouse osteoblasts [17, 26], neonatal mouse calvaria [27], and mouse peritoneal macrophages from cadmium-exposed mice (15 ppm Cd through drinking water for 2 months) [24].

In our study, co-incubation of macrophages with cadmium and selective COX-2 inhibitor NS-398 for $48 \mathrm{~h}$ resulted in significant dose-dependent increase in $\mathrm{PGE}_{2}$ concentration. This was an unexpected result, since previous reports showed inhibitory action of NS-398 on cadmium-stimulated $\mathrm{PGE}_{2}$ production in other cell lines [17, 27]. Maybe the increase in $\mathrm{PGE}_{2}$ levels following NS-398 treatment in cadmium-exposed macrophages was the consequence of paradoxical effect of NS-398 in our culture system and experimental conditions.

\section{Cadmium and Thromboxane $\mathrm{B}_{2}$ Synthesis by THP-1 Macrophages}

Cadmium at concentrations and exposure duration tested in our study did not significantly modulate $\mathrm{TXB}_{2}$ production by THP-1 macrophages. This result is in concert with report of Eisenmann and Miller who analyzed the effects of cadmium on human placental production of $\mathrm{TXB}_{2}$ : two $12 \mathrm{~h}$ exposures to cadmium (40 and $100 \mu \mathrm{M}$ ) caused no significant effect on $\mathrm{TXB}_{2}$ levels [28].

The treatment of THP- 1 macrophages with both $2 \mu \mathrm{M}$ cadmium and NS-398 for $48 \mathrm{~h}$ resulted in increase in $\mathrm{TXB}_{2}$ concentration as compared with control. This may also be the consequence of paradoxical effect of NS-398 in our culture system. As was suggested by Ziemann et al., may be the loss of antiinflammatory efficacy of COX-2 selective inhibitor NS-398 at higher doses occurs through paradoxical activation of NF- $\mathrm{KB}$ and subsequent induction of NF-kB-dependent proinflammatory genes [42]. Blais et al. demonstrated that COX2 inhibition increases inflammatory response in the brain during systemic immune stimuli [35]. Gilroy and colleagues showed in carrageenan-induced inflammation model in rats that NS-398 significantly exacerbated inflammation at $48 \mathrm{~h}$ [43].

The fact that significantly increased COX-1 and COX-2 mRNA expression at $2 \mu \mathrm{M}$ Cd were not accompanied with increased protein and enzymatic activity levels remains to be resolved. Sovago and Varnagy demonstrated that cadmium(II) ions may form complexes with all natural amino acids and peptides [44]. Among the most effective metal binding amino acids are cysteine, methionine, aspartic acid, and histidine [44]. Twenty-four amino acid residues were found to line cyclooxygenase active site with only one difference between COX-1 and COX-2 [45]. Maybe the lack of alterations in COX-1 and COX-2 enzymatic activities is associated with cadmium interaction with some amino acid residues that constitute the active sites of these enzymes, leading to enzyme conformational changes affecting the catalytic efficiency of cyclooxygenases through decreased substrate binding.

\section{Conclusion}

In conclusion, our study demonstrates that cadmium at the highest tested concentrations modulates COX-1 and COX-2 only at mRNA level in THP-1 macrophages; however, the lower tested cadmium concentrations appear to inhibit COX1 protein expression. The stimulatory effect of cadmium on COXs at mRNA level is not reflected at protein and enzymatic activity levels, suggesting the existence of some posttranscriptional, translational, and posttranslational events that result in silencing of those genes' expression.

Despite the minimal effect of cadmium on COXs found in this study, we may not exclude the possible cumulative effect of its action in such low concentrations, which will be the topic of our future research.

Acknowledgments The study was funded by the Pomeranian Medical University, Szczecin, Poland.

Conflict of Interest The authors declare that there is no conflict of interests regarding the publication of this paper.

Open Access This article is distributed under the terms of the Creative Commons Attribution License which permits any use, distribution, and reproduction in any medium, provided the original author(s) and the source are credited.

\section{References}

1. Kurumbail RG, Kiefer JR, Marnett LJ (2001) Cyclooxygenase enzymes: catalysis and inhibition. Curr Opin Struct Biol 11:752-760

2. Smith CJ, Zhang Y, Koboldt CM, Muhammad J, Zweifel BS, Shaffer A, Talley JJ, Masferrer JL, Seibert K, Isakson PC (1998) Pharmacological analysis of cyclooxygenase-1 in inflammation. Proc Natl Acad Sci USA 95:13313-13318 
3. Rouzer CA, Marnett LJ (2009) Cyclooxygenases: structural and functional insights. J Lipid Res 50:S29-S34

4. Morita I (2002) Distinct functions of COX-1 and COX-2. Prostaglandins Other Lipid Mediat 68-69:165-175

5. Gilroy DW, Colville-Nash PR (2000) New insights into the role of COX-2 in inflammation. J Mol Med (Berl) 78:121-129

6. Khan AA, Iadarola M, Yang HY, Dionne RA (2007) Expression of COX-1 and COX-2 in a clinical model of acute inflammation. J Pain 8:349-354

7. Kang YJ, Mbonye UR, DeLong CJ, Wada M, Smith WL (2007) Regulation of intracellular cyclooxygenase levels by gene transcription and protein degradation. Prog Lipid Res 46:108-125

8. Park YK, Hong H, Jang BC (2012) Transcriptional and translational regulation of COX-2 expression by cadmium in $\mathrm{C} 6$ glioma cells. Int $\mathrm{J}$ Mol Med 30:960-966

9. Harper KA, Tyson-Capper AJ (2008) Complexity of COX-2 gene regulation. Biochem Soc Trans 36:543-545

10. Hartwig A (2010) Mechanisms in cadmium-induced carcinogenicity: recent insights. Biometals 23:951-960

11. Olszowski T, Baranowska-Bosiacka I, Gutowska I, Chlubek D (2012) Pro-inflammatory properties of cadmium. Acta Biochim Pol 59:475-482

12. Skoczyńska A, Poreba R, Sieradzki A, Andrzejak R, Sieradzka U (2002) The impact of lead and cadmium on the immune system. Med Pr 53:259-264

13. International Agency for Research on Cancer (2012) Cadmium and cadmium compounds, In: Arsenic, metals, fibres and dusts. A review of human carcinogens. IARC Monogr 100C:121-145

14. Ahn SI, Park SK, Lee MY, Youn HS (2009) Cadmium but not mercury suppresses NF-kappa B activation and COX-2 expression induced by Toll-like receptor 2 and 4 agonists. Mol Cell Toxicol 5:141-146

15. Bernhard D, Rossmann A, Henderson B, Kind M, Seubert A, Wick G (2006) Increased serum cadmium and strontium levels in young smokers: effects on arterial endothelial cell gene transcription. Arterioscler Thromb Vasc Biol 26:833-838

16. Figueiredo-Pereira ME, Li Z, Jansen M, Rockwell P (2002) NAcetylcysteine and celecoxib lessen cadmium cytotoxicity which is associated with cyclooxygenase-2 up-regulation in mouse neuronal cells. J Biol Chem 277:25283-25289

17. Miyahara T, Tonoyama H, Watanabe M, Okajima A, Miyajima S, Sakuma T, Nemoto N, Takayama K (2001) Stimulative effect of cadmium on prostaglandin E2 production in primary mouse osteoblastic cells. Calcif Tissue Int 68:185-191

18. Seok SM, Park DH, Kim YC, Moon CH, Jung YS, Baik EJ, Moon CK, Lee SH (2006) COX-2 is associated with cadmium-induced ICAM-1 expression in cerebrovascular endothelial cells. Toxicol Lett 165:212-220

19. Shin HJ, Park KK, Lee BH, Moon CK, Lee MO (2003) Identification of genes that are induced after cadmium exposure by suppression subtractive hybridization. Toxicology 191:121-131

20. Alvarez SM, Gómez NN, Scardapane L, Zirulnik F, Martínez D, Giménez MS (2004) Morphological changes and oxidative stress in rat prostate exposed to a non-carcinogenic dose of cadmium. Toxicol Lett 153:365-376

21. Kundu S, Sengupta S, Chatterjee S, Mitra S, Bhattacharyya A (2009) Cadmium induces lung inflammation independent of lung cell proliferation: a molecular approach. J Inflamm (Lond) 6:19

22. Lee J, Lim KT (2011) Inhibitory effect of plant-originated glycoprotein $(27 \mathrm{kDa})$ on expression of matrix metalloproteinase-9 in cadmium chloride-induced BNL CL.2 cells. J Trace Elem Med Biol 25:239-246

23. Morales AI, Vicente-Sánchez C, Jerkic M, Santiago JM, SánchezGonzález PD, Pérez-Barriocanal F, López-Novoa JM (2006) Effect of quercetin on metallothionein, nitric oxide synthases and cyclooxygenase- 2 expression on experimental chronic cadmium nephrotoxicity in rats. Toxicol Appl Pharmacol 210:128-135
24. Ramirez DC, Gimenez MS (2003) Induction of redox changes, inducible nitric oxide synthase and cyclooxygenase- 2 by chronic cadmium exposure in mouse peritoneal macrophages. Toxicol Lett 145:121-132

25. Rockwell P, Martinez J, Papa L, Gomes E (2004) Redox regulates COX-2 upregulation and cell death in the neuronal response to cadmium. Cell Signal 16:343-353

26. Miyahara T, Katoh T, Watanabe M, Mikami Y, Uchida S, Hosoe M, Sakuma T, Nemoto N, Takayama K, Komurasaki T (2004) Involvement of mitogen-activated protein kinases and protein kinase $\mathrm{C}$ in cadmium-induced prostaglandin E2 production in primary mouse osteoblastic cells. Toxicology 200:159-167

27. Romare A, Lundholm CE (1999) Cadmium-induced calcium release and prostaglandin E2 production in neonatal mouse calvaria are dependent on Cox-2 induction and protein kinase $\mathrm{C}$ activation. Arch Toxicol 73:223-228

28. Eisenmann CJ, Miller RK (1995) Cadmium and glutathione: effect on human placental thromboxane and prostacyclin production. Reprod Toxicol 9:41-48

29. Qin Z (2012) The use of THP-1 cells as a model for mimicking the function and regulation of monocytes and macrophages in the vasculature. Atherosclerosis 221:2-11

30. Luparello C, Sirchia R, Longo A (2011) Cadmium as a transcriptional modulator in human cells. Crit Rev Toxicol 41:75-82

31. Waisberg M, Joseph P, Hale B, Beyersmann D (2003) Molecular and cellular mechanisms of cadmium carcinogenesis. Toxicology 192:95-117

32. Beyersmann D, Hartwig A (2008) Carcinogenic metal compounds: recent insight into molecular and cellular mechanisms. Arch Toxicol 82:493-512

33. Tanabe $\mathrm{T}$, Tohnai $\mathrm{N}$ (2002) Cyclooxygenase isozymes and their gene structures and expression. Prostaglandins Other Lipid Mediat 68-69: 95-114

34. Callejas NA, Castrillo A, Boscá L, Martín-Sanz P (1999) Inhibition of prostaglandin synthesis up-regulates cyclooxygenase- 2 induced by lipopolysaccharide and peroxisomal proliferators. J Pharmacol Exp Ther 288:1235-1241

35. Blais V, Turrin NP, Rivest S (2005) Cyclooxygenase 2 (COX-2) inhibition increases the inflammatory response in the brain during systemic immune stimuli. J Neurochem 95:1563-1574

36. Barrios-Rodiles M, Keller K, Belley A, Chadee K (1996) Nonsteroidal antiinflammatory drugs inhibit cyclooxygenase-2 enzyme activity but not mRNA expression in human macrophages. Biochem Biophys Res Commun 225:896-900

37. Gry M, Rimini R, Strömberg S, Asplund A, Pontén F, Uhlén M, Nilsson P (2009) Correlations between RNA and protein expression profiles in 23 human cell lines. BMC Genomics 10:365

38. Mbonye UR, Song I (2009) Posttranscriptional and posttranslational determinants of cyclooxygenase expression. BMB Rep 42:552-560

39. Othumpangat S, Kashon M, Joseph P (2005) Eukaryotic translation initiation factor $4 \mathrm{E}$ is a cellular target for toxicity and death due to exposure to cadmium chloride. J Biol Chem 280:25162-25169

40. Dixon DA, Kaplan CD, McIntyre TM, Zimmerman GA, Prescott SM (2000) Post-transcriptional control of cyclooxygenase-2 gene expression. The role of the 3'-untranslated region. J Biol Chem 275:11750-11757

41. Fabbri M, Urani C, Sacco MG, Procaccianti C, Gribaldo L (2012) Whole genome analysis and microRNAs regulation in HepG2 cells exposed to cadmium. ALTEX 29:173-182

42. Ziemann C, Schäfer D, Rüdell G, Kahl GF, Hirsch-Ernst KI (2002) The cyclooxygenase system participates in functional mdr1b overexpression in primary rat hepatocyte cultures. Hepatology 35:579-588

43. Gilroy DW, Colville-Nash PR, Willis D, Chivers J, Paul-Clark MJ, Willoughby DA (1999) Inducible cyclooxygenase may have antiinflammatory properties. Nat Med 5:698-701

44. Sóvágó I, Várnagy K (2013) Cadmium (II) complexes of amino acids and peptides. Met Ions Life Sci 11:275-302

45. Smith WL, DeWitt DL, Garavito RM (2000) Cyclooxygenases: structural, cellular, and molecular biology. Annu Rev Biochem 69: $145-182$ 